\title{
Killing Weed Seeds with Exhaust Gas from a Combine Harvester
}

\author{
Klaus Jakobsen ${ }^{\dagger}$, Jakob A. Jensen ${ }^{\dagger}$, Zahra Bitarafan $\mathbb{D}$ and Christian Andreasen *(D) \\ Department of Plant and Environmental Sciences, Faculty of Science, University of Copenhagen, \\ Højbakkegaard Allé 13, Taastrup DK 2630, Denmark \\ * Correspondence: can@plen.ku.dk; Tel.: +45-3534-3353 \\ † The authors contributed equally.
}

Received: 16 August 2019; Accepted: 11 September 2019; Published: 12 September 2019

\begin{abstract}
We investigated if hot exhaust gas from a combine harvester could be used to reduce germination or kill weed seeds during the harvesting process. During the threshing and cleaning process in the combine, weed seeds and chaff are separated from the crop grains. After this separation, weed and crop seeds not collected can be exposed to exhaust gas before seeds are returned to the field. Seeds of some common weed species (Alopecurus myosuroides, Centaurea cyanus, Geranium pusillum, Lapsana communis, Lolium perenne, Rumex crispus, Spergula arvensis, and Tripleurospermum inodorum) were treated with exhaust gas at temperatures of $75^{\circ} \mathrm{C}$ or $85^{\circ} \mathrm{C}, 110^{\circ} \mathrm{C}$, and $140{ }^{\circ} \mathrm{C}$ for 2,4 , and $6 \mathrm{~s}$, respectively. Afterwards, the seeds were germinated for 16 days. We found that $75^{\circ} \mathrm{C}$ and $85^{\circ} \mathrm{C}$ were insufficient to significantly reduce germination of the seeds after three durations. Some seeds were still able to germinate after $4 \mathrm{~s}$ exposure of $110{ }^{\circ} \mathrm{C}$. An exposure of $140{ }^{\circ} \mathrm{C}$ for 4 and $6 \mathrm{~s}$ repressed germination of all species. We conclude that there is potential to develop combine harvesters that exploit the exhaust gas to either kill or reduce the ability of weed seeds to germinate before seeds are returned to the field.
\end{abstract}

Keywords: heat treatments; seed viability; soil seed bank; thermal weed control; weed avoidance

\section{Introduction}

Weeds are one of the most devastating constraints for crop production worldwide [1]. Since the 1950s, herbicides have been widely used with great success, but herbicide-resistant weeds have become a growing problem in agriculture [2], and international trade and traffic have contributed to spreading seeds and plant parts, resulting in increasing problems with invasive weeds. The possibilities of developing new and effective herbicides seem to be exhausted. No new herbicide mode of action has been discovered since the 1980s, and many herbicides have been banned due to risks of unwanted side effects [3]. The extensive use of herbicides has resulted in increasing public concerns, and this has led to further restrictions for herbicide use in Europe and elsewhere [4,5]. Furthermore, there is an increasing public interest in organic food [6]. This situation calls for integrated weed management approaches to reduce weed problems in the future. A stronger focus on crop rotation and soil tillage seems to be the main alternative to herbicides $[7,8]$, but there is also a need for developing new techniques to replace and supplement present weed control methods.

Robinson and Sutherland [9] showed a general, nearly linear decline in the numbers of weed seeds in arable soils in the period from the 1920s to the 1990s in Great Britain, probably due to massive use of herbicides and fertilizer, which made the crop very competitive against weeds. However, since then, the trend has decreased or even reversed. Andreasen et al. [10] studied the soil seed banks in the Danish fields in the same locations 25 and 50 years after the first survey in 1964. In 1964, Andreasen et al. [10] estimated the number of viable seeds in the ploughing layer to be 19,390 seeds $\mathrm{m}^{-2}$. In 1989, the number 
was reduced to 10,120 seeds $\mathrm{m}^{-2}$, probably because of the introduction and the use of many new herbicides [11], but this number increased again to 20,455 seeds $\mathrm{m}^{-2}$ in 2014.

The seed banks of many problematic annual weed species decay rapidly. For example, A. myosuroides, Avena spica-venti, and Poa annua, which are common weeds in autumn sown cereals in Northern Europe, all have a seed bank decaying in a few years [12-14]. If new input of such seeds is reduced, a large seed bank can be reduced to a modest one in a few years. A small weed seed bank potentially makes weed control easier and reduces the risk of evolution of herbicide resistant populations. However, many dicot species can persist in the soil seed bank for decades $[15,16]$. For crop producers using a combine harvester, harvest time represents an opportunity to collect and destroy weed seeds and thereby prevent inputs into the weed seed bank. For many of the weed species, fruits remain intact at the time of maturity, and a proportion of the seeds may be retained at a height that ensures a significant amount can be collected during crop harvest.

A conventional combine harvester collects the weed seeds and separates most of them together with the chaff from the grains. Then, it expels the fraction (mostly in the chaff) and returns it to the field, creating weed problems for the following growing seasons. Some systems target weed seeds during commercial grain harvest operations and act to minimize seed inputs to the seed bank [14]. Chaff can be transported into a bulk collection bin attached to a grain harvester using a transfer mechanism that delivers the weed seed bearing chaff fraction. The fraction can then be removed from the field or dumped in chaff heaps and subsequently burned [14]. During harvesting, all of the exiting chaff and straw residues can also be concentrated into a narrow-windrow $(500-600 \mathrm{~mm})$ by a chaff chute mounted on the rear of a harvester. Later, the chaff can be burned to avoid burning the entire crop field [14]. Due to fire risk and smoke pollution, burning of chaff may not be allowed or appropriate, and removal of organic matter not used for food, feed, or fuel incurs additional costs for the farmer.

In contrast, returning organic matter to the field contributes to maintain the water holding capacity and the fertility of the soil. The Harrington Seed Destructor (HSD) uses a cage mill to crush the chaff [17]. Cage mills have been developed for a wide variety of uses, such as to crush rocks and other materials [18]. The HSD consists of a diesel motor and a cage mill mounted on a trailer with a chaff and a straw transfer system. The trailer is mounted on the harvester. The HSD has been able to destroy 95\% of Lolium rigidum Gaudin in the chaff fraction of harvest residues [17]. However, the HSD system also results in additional costs regarding energy and machine investment.

We explored the possibility of using exhaust gas from a combine harvester to kill the weed seeds before they are returned to the field. Exhaust gas is a waste product with temperatures up to $480{ }^{\circ} \mathrm{C}$ [19], and it might be beneficial for the farmer to use it in an integrated weed management strategy, for example, in combination with other mechanical and/or thermal weed control strategies.

The objective of this study was to investigate how the germination of some selected weed seeds was affected by heat treatment with exhaust gas. If the exhaust gas can kill weed seeds or reduce seed germination significantly, it may open new perspectives to develop an integrated system with heat in the combine harvester based on exhaust gas.

\section{Materials and Methods}

\subsection{Experiments}

The experiments were conducted at the research station Højbakkegaard, University of Copenhagen, Department of Plant and Environmental Sciences, Taastrup, Denmark ( $\left.55^{\circ} 40^{\prime} 8.16^{\prime \prime} \mathrm{N} ; 12^{\circ} 18^{\prime} 18.82^{\prime \prime} \mathrm{E}\right)$.

Eight weed species were chosen for the experiments [Alopecurus myosuroides Huds., Centaurea cyanus L., Geranium pusillum L., Lapsana communis L., Lolium perenne L., Rumex crispus L., Spergula arvensis L., and Tripleurospermum inodorum (L) Sch. Bip.]. We chose species that were very different in seed morphology, size, and weight to represent a broad spectrum of common weed species in Northern Europe (Table 1). 
Table 1. Descriptions of the weed seeds exposed to exhaust gas from an experimental combine harvester [20-22].

\begin{tabular}{|c|c|c|c|c|}
\hline Weed Species & Short Description & $\begin{array}{c}\text { Thousand Seed } \\
\text { Weight (g) }\end{array}$ & $\begin{array}{l}\text { Size } \\
(\mathrm{mm})\end{array}$ & $\begin{array}{l}\text { Plant Height } \\
\text { (cm) }\end{array}$ \\
\hline $\begin{array}{c}\text { Alopecurus myosuroides } \\
\text { Huds. }\end{array}$ & $\begin{array}{l}\text { Spikelet with one seed and } \\
\text { with a 5-6 } \mathrm{mm} \text { awn }\end{array}$ & 2.0 & $5.7 \times 1.9 \times 0.9$ & $20-60$ \\
\hline Centaurea cyanus L. & $\begin{array}{c}\text { Seed with stiff hairs }(4 \mathrm{~mm}) \\
\text { at the apex }\end{array}$ & 4.5 & $2.4 \times 1.7 \times 1.2$ & $20-80$ \\
\hline Geranium pusillum L. & Cross-section round & 1.1 & $1.1 \times 1.1 \times 1.1$ & $5-30$ \\
\hline Lapsana communis L. & Cross-section oval to elliptic & 1.1 & $3.7 \times 0.9 \times 0.6$ & $20-120$ \\
\hline Lolium perenne L. & Cross-section c-shaped & 2.0 & $6.6 \times 1.4 \times 1.0$ & $20--60$ \\
\hline Rumex $\times$ crispus L. & Cross-section triangular & 1.4 & $2.2 \times 1.5 \times 1.5$ & $40-100$ \\
\hline Spergula arvensis L. & Cross-section oval & 0.5 & $1.2 \times 1.2 \times 0.8$ & $10-30$ \\
\hline $\begin{array}{l}\text { Tripleurospermum } \\
\text { inodorum (L) Sch. Bip. }\end{array}$ & $\begin{array}{c}\text { Cross-section triangular } \\
\text { to square }\end{array}$ & 0.4 & $1.8 \times 0.7 \times 0.7$ & $20-80$ \\
\hline
\end{tabular}

Seeds were collected in July and August 2016 from the fields of the research station and stored at $5{ }^{\circ} \mathrm{C}$. The seed lots had a germination rate between 66 and $96 \%$ in 2017. Two series of experiments were conducted. The first series was conducted 15 March 2017 for S. arvensis, G. pusillum, L. communis, T. inodorum, A. myosuroides, and C. cyanus and 23 March 2017 for L. perenne and R. crispus. The second series was conducted 20 June 2017 for S. arvensis, G. pusillum, L. communis, and T. inodorum and 23 June 2017 for A. myosuroides, C. cyanus, L. perenne, and R. crispus. The ambient temperatures were $8{ }^{\circ} \mathrm{C}$ for the first series and $21^{\circ} \mathrm{C}$ for the second series.

Seeds were exposed to the exhaust gas from a small experimental combine harvester (Haldrup Plor Combine C-85, Løgstør, Denmark). The engine (Deutz diesel, type BF4L914, 67 kW/91 hp, Cologne, Germany) was running for $20 \mathrm{~min}$ before treatment to ensure a stable temperature. The temperature of exhaust gas was recorded approximately $2 \mathrm{~cm}$ from the exhaust pipe using a digital thermometer (DURAC ${ }^{\circledR}$ Precision thermometer, H-B instrument Company, Wayne, NJ, USA) before each species was treated. Seeds were placed in a round pincer filter (diameter $5 \mathrm{~cm}$ ) and held directly above the exhaust pipe (Figure 1).

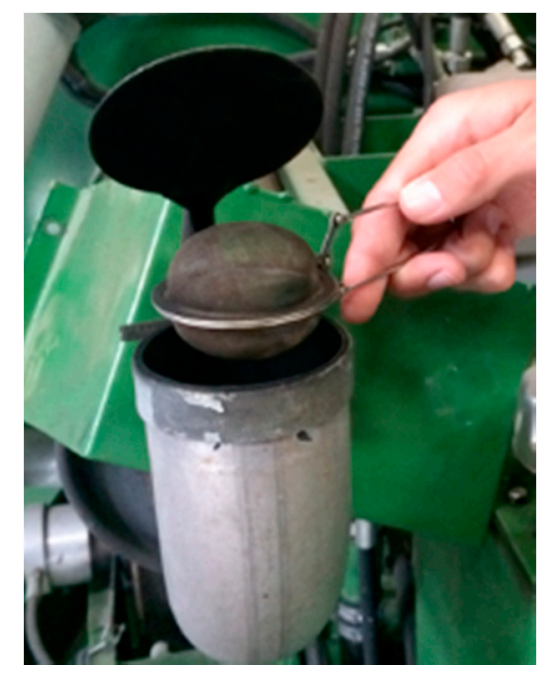

Figure 1. The exhaust pipe and the filter with weed seeds.

An anemometer (Skywatch Xplorer 1, JDC Electronic SA, Yverdon-les-bains, Switzerland) was used to measure the velocity of the heated exhaust gas. At idle, the engine reached approximately $75^{\circ} \mathrm{C}$ for the first series of experiments (series 1). The experiments were repeated later (series 2), but then the temperature could not be lowered to less than $85^{\circ} \mathrm{C}$ because the ambient temperature had increased 
by $13{ }^{\circ} \mathrm{C}$. We prevented temperature variation by keeping the throttle at the position that resulted in the desired temperatures, and we monitored the exhaust gas temperature with a thermometer continuously during the experiments (Table 2).

Table 2. Measurements of the exhaust gas features from the combine harvester.

\begin{tabular}{cccccc}
\hline & \multicolumn{5}{c}{ Engine Setting } \\
\cline { 2 - 6 } & Unit & Idle & $\mathbf{3 0 \%}$ & $\mathbf{5 0 \%}$ & $\mathbf{1 0 0 \%}$ \\
\hline Temperature & ${ }^{\circ} \mathrm{C}$ & 75 or 85 & 110 & 140 & 220 \\
Air speed & $\mathrm{m} \mathrm{s}^{-1}$ & 21.4 & 23.8 & 24.0 & 38.0 \\
Air flow & $\mathrm{L} \mathrm{min}^{-1}$ & 508 & 565 & 570 & 902 \\
\hline
\end{tabular}

Considering both the time it takes seeds to pass through the combine harvester and the risk of fire at high exhaust gas temperatures, we chose three temperatures for the heat treatment of the seeds based on earlier studies [23]. Seeds in the round pincer filter (Figure 1) were exposed to three temperatures $\left(75^{\circ} \mathrm{C}\right.$ or $85^{\circ} \mathrm{C}, 110^{\circ} \mathrm{C}$, and $\left.140{ }^{\circ} \mathrm{C}\right)$ and three durations $(2,4$, and $6 \mathrm{~s})$. Each treatment was done four times per species with fifty seeds. The lowest temperatures we could obtain were $75^{\circ} \mathrm{C}$ or $85^{\circ} \mathrm{C}$. The day after, the seeds were germinated in germination boxes $(120 \times 80 \times 50 \mathrm{~mm})$ and placed in a Termaks KB8000L climate chamber (Termaks AS, Nino lab, Køge, Denmark) with a diurnal cycle of $12 \mathrm{~h} / 12 \mathrm{~h}$ light/dark at a constant temperature of $15^{\circ} \mathrm{C}$. Each box contained a plastic spacer $(110 \times 75 \times$ $20 \mathrm{~mm}$ ) with a cellulose filter paper wick (Frisenette AGF $725-18 \times 200 \mathrm{~mm}$ ) sucking the water to a filter paper (Frisenette AGF $725-73 \times 113 \mathrm{~mm}$ ) on top. The boxes were filled with $100 \mathrm{~mL}$ demineralized water, and the fifty seeds were placed on the filter paper. Lids were placed on the boxes. Seeds were not treated with $\mathrm{KNO}_{3}$ or any other treatment to release dormancy and increase the germination percentage. Germinated seeds were counted and removed every $24 \mathrm{~h}$. The controls (unheated seeds) were also germinated at $15^{\circ} \mathrm{C}$. The germination experiments were terminated after 16 days. A seed was considered germinated when it had developed a radicle of $2 \mathrm{~mm}$. In total, 32,000 seeds were investigated [50 seeds $\times 4$ replicates $\times 3$ durations $\times 3$ temperatures $\times 8$ species $\times 2$ experiments + $(4 \times 50$ seeds for controls $\times 2$ experiments $\times 8$ species $)]$.

\subsection{Statistical Analysis}

For each combination of species and temperature, a model was fitted. The germination was modeled with the function $F(t)$ [Equation (1)] using the add-on package $d r c$ [24].

$$
F(t)=\frac{d}{1+\exp \left[b\left\{\log (t)-\log \left(t_{50}\right)\right\}\right]}
$$

$F(t)$ denotes the fraction of seeds germinating between the onset of the experiment (at time 0 ) and the time $t$ (days). The upper limit parameter $d$ denotes the proportion of seeds that germinated during the 16 days. The parameter $b$ is proportional to the slope of $F$ at time $t$ equal to the parameter $t_{50}$, which denotes the time where $50 \%$ of the seeds (those that germinated during the experimental period) germinated. The estimation and the model checking procedures were based on treating the data as event times to record the time it took for germination (the event of interest) to occur, as described by Ritz et al. [25]. The assessments of the individual fits were done by inspecting the graphical analysis of the residuals. Post hoc comparisons of parameters were based on pairwise t-tests adjusted for multiple testing using the single step approach (Tukey's range test) implemented in the extension package $d r c$ multcomp [26].

\section{Results}

Untreated seeds of seven of the weed species had a germination percentage above $70 \%$ (except in the case of A. myosuroides series 1, which was 66\%) and reached the upper limit ( $d$ parameter) within ten 
days (Table 3, Figure 2). The effects of the different temperatures applied for $2 \mathrm{~s}$ are shown for series 1 in Figure 2 and for series 2 in Figure 3. Treatment with $75^{\circ} \mathrm{C}$ and $85^{\circ} \mathrm{C}$ for $2 \mathrm{~s}$ significantly affected the germination percentage of $A$. myosuroides in series $1(p$-value $=0.01)$ and $R$. crispus in series 1 and $2(p$-value $=0.05)($ Table 3$)$, although there seemed to be a tendency of increased germination for all species (Figures 2 and 3). Increasing the duration of exposure to 4 and $6 \mathrm{~s}$ resulted-in most cases-in a slightly lower germination percentage and higher $t_{50}$ compared to $2 \mathrm{~s}$ and the control. Seed samples of all species had germination rates exceeding $46 \%$ at an exposure time of $6 \mathrm{~s}$ (Table 3). When seed samples were exposed to $110{ }^{\circ} \mathrm{C}$ for $2 \mathrm{~s}$, germination was reduced, and $t_{50}$ increased significantly according to the Tukey range test for all species compared to untreated seed samples (Figures 2 and 3 , Table 4). However, the species responded very differently. In particular, the germination of S. arvensis, L. communis, and T. inodorum declined significantly. When seed samples were exposed to $110^{\circ} \mathrm{C}$ for $4 \mathrm{~s}$, only some seeds of L. communis, C. cyanus, and A. myosuroides were still able to germinate, but in the second series, this was only the case for $C$. cyanus. Seed samples exposed to $110^{\circ} \mathrm{C}$ for $6 \mathrm{~s}$ died except a small fraction of $S$. arvensis (Table 4).
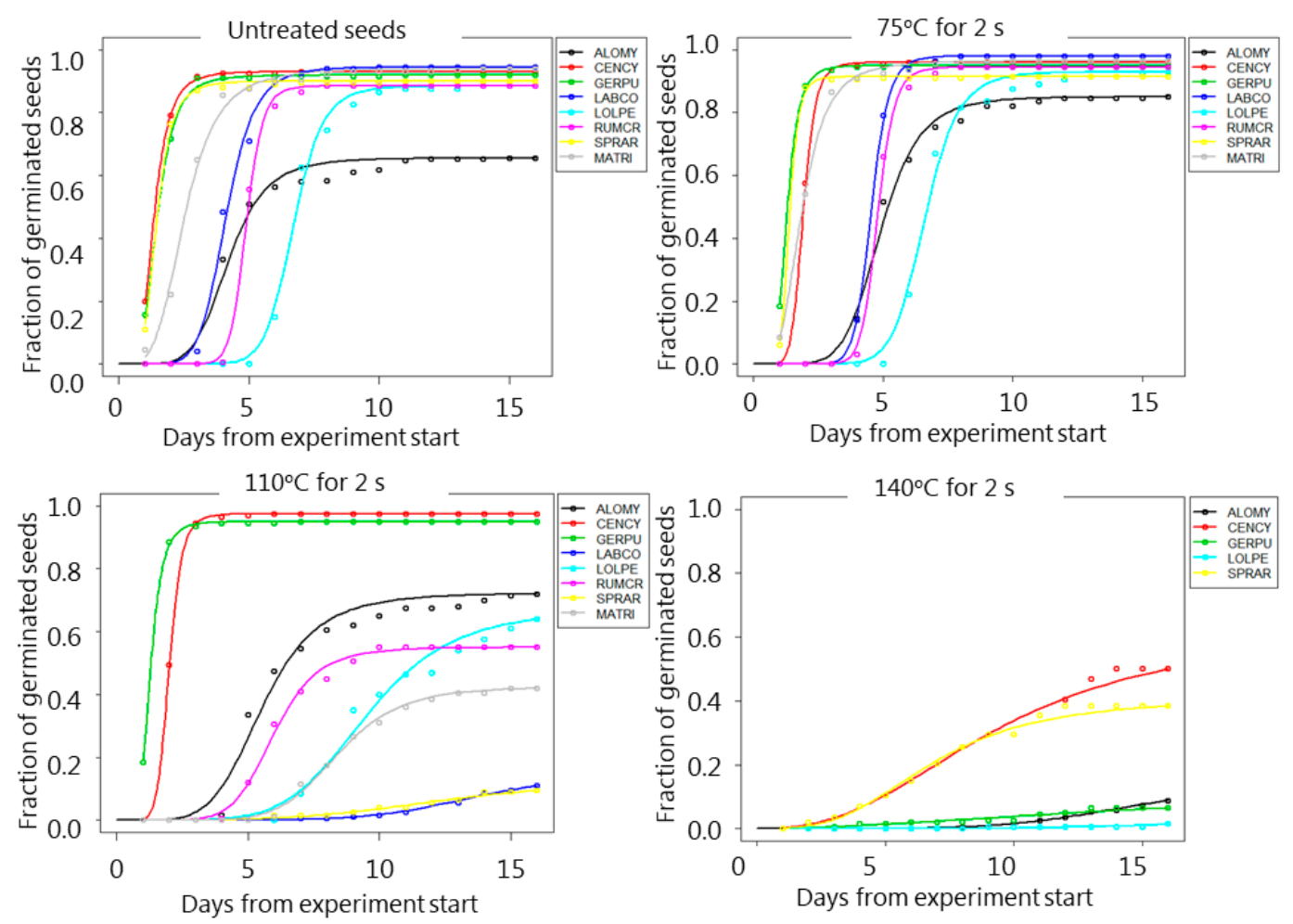

Figure 2. Series 1. Germination curves of weed seeds after they were exposed to exhaust gas for $2 \mathrm{~s}$ at temperatures of $75^{\circ} \mathrm{C}, 110^{\circ} \mathrm{C}$, and $140{ }^{\circ} \mathrm{C}$, respectively. A. myosuroides = ALOMY; C. cyanus = CENCY; G. pusillum $=$ GERPU; L. communis $=\mathrm{LAPCO} ;$ L. perenne $=\mathrm{LOLPE} ;$ R. crispus $=$ RUMCR; . arvensis $=$ SPRAR; . inodorum $=$ MATIN. Species not shown at $140{ }^{\circ} \mathrm{C}$ did not germinate. Points are means of exact counts. Lines are estimated germination curves base on counts [see Equation (1)]. 
Table 3. Results of heat treatments at exhaust gas temperatures of $75^{\circ} \mathrm{C}$ and $85{ }^{\circ} \mathrm{C}$ for durations of 2,4 , and $6 \mathrm{~s}$ with standard errors ( ). $d \times 100$ denotes the percentage of seeds that germinated during the experiment (\%). $t_{50}$ denotes the time (days) when $50 \%$ of the seeds (that germinated during the 16 days) had germinated. All species parameters, which were significantly different, are marked with different letters.

\begin{tabular}{|c|c|c|c|c|c|c|c|c|c|}
\hline \multirow[b]{3}{*}{ Species } & \multirow[b]{3}{*}{ Series } & \multicolumn{8}{|c|}{ Treatment at $75^{\circ} \mathrm{C}$ in Series 1 and $85^{\circ} \mathrm{C}$ in Series 2} \\
\hline & & \multicolumn{2}{|c|}{ Control } & \multicolumn{2}{|c|}{$2 \mathrm{~s}$} & \multicolumn{2}{|c|}{$4 \mathrm{~s}$} & \multicolumn{2}{|c|}{$6 \mathrm{~s}$} \\
\hline & & $d$ & $t_{50}$ & $d$ & $t_{50}$ & $d$ & $t_{50}$ & $d$ & $t_{50}$ \\
\hline Alopecurus myosuroides & 1 & $66(3)^{a}$ & $4.2(0.1)^{\mathrm{a}}$ & $85(3) b$ & $4.9(0.1)^{b}$ & $86(3)^{b}$ & $4.8(0.1)^{\mathrm{b}}$ & $82(3)^{b}$ & $5.1(0.1)^{\mathrm{c}}$ \\
\hline Alopecurus myosuroides & 2 & $77(3)^{a}$ & $5.3(0.1)^{\mathrm{a}}$ & $83(3)^{a b}$ & $5.2(0.1)^{a}$ & $85(3)^{b}$ & $5.2(0.1)^{\mathrm{a}}$ & $81(3)$ ab & $5.4(0.1)^{\mathrm{a}}$ \\
\hline Centaurea cyanus & 1 & $93(2)^{a}$ & $1.3(0.1)^{\mathrm{a}}$ & $96(1)^{a}$ & $1.9(0.0)^{b}$ & $96(1)^{a}$ & $2.1(0.0)^{\mathrm{c}}$ & $98(1)^{b}$ & $2.5(0.1)^{d}$ \\
\hline Centaurea cyanus & 2 & $96(1)^{a}$ & $2.8(0.0)^{\mathrm{a}}$ & $95(2)^{a}$ & $2.6(0.1)^{b}$ & $92(2)^{a}$ & $2.6(0.0)^{b}$ & $93(2)^{a}$ & $2.8(0.0)^{\mathrm{a}}$ \\
\hline Geranium pusillum & 1 & $92(2)^{a}$ & $1.5(0.1)^{\mathrm{a}}$ & $95(2)^{a}$ & $1.3(0.0)^{b}$ & $95(2)^{a}$ & $1.4(0.0)^{\mathrm{a}}$ & $86(3)^{b}$ & $1.9(0.1)^{\mathrm{c}}$ \\
\hline Geranium pusillum & 2 & $90(2)^{a}$ & $1.8(0.0)^{\mathrm{a}}$ & $94(2)^{a}$ & $1.8(0.0)^{\mathrm{a}}$ & $90(2)^{a}$ & $2.1(0.0)^{b}$ & $82(3) b$ & $3.0(0.1)^{c}$ \\
\hline Lapsana communis & 1 & $95(2)^{a}$ & $4.1(0.1)^{\mathrm{a}}$ & $98(1)^{a}$ & $4.5(0.1)^{b}$ & $96(1)^{\mathrm{a}}$ & $6.5(0.1)^{c}$ & $71(3)^{b}$ & $9.1(0.2)^{d}$ \\
\hline Lapsana communis & 2 & $90(2)^{a}$ & $4.5(0.1)^{\mathrm{a}}$ & $93(2)^{a}$ & $4.9(0.1)^{b}$ & $84(3)^{a b}$ & $9.3(0.2)^{c}$ & $47(4)^{c}$ & $12.3(0.2) \mathrm{d}$ \\
\hline Lolium perenne & 1 & $89(2)^{a}$ & $6.7(0.1)^{\mathrm{a}}$ & $93(2)^{a}$ & $6.6(0.1)^{a}$ & $90(2)^{a}$ & $6.6(0.1)^{a}$ & $89(2)^{a}$ & $7.7(0.1)^{b}$ \\
\hline Lolium perenne & 2 & $85(3)^{a}$ & $6.8(0.1)^{\mathrm{a}}$ & $91(2)^{a b}$ & $6.8(0.1)^{a}$ & $92(2)^{b}$ & $6.9(0.1)^{\mathrm{a}}$ & $83(3)^{a b}$ & $7.7(0.1)^{b}$ \\
\hline Tripleurospermum inodorum & 1 & $94(2)^{a}$ & $2.5(0.1)^{\mathrm{a}}$ & $97(1)^{a}$ & $1.9(0.1)^{b}$ & $96(1)^{a}$ & $3.6(0.1)^{c}$ & $83(3) b$ & $6.9(0.2) \mathrm{d}$ \\
\hline Tripleurospermum inodorum & 2 & $92(2)^{a}$ & $3.9(0.1)^{a}$ & $92(2)^{a}$ & $4.3(0.1)^{b}$ & $80(3)^{b}$ & $9.8(0.2)^{\mathrm{c}}$ & $64(3)^{c}$ & $10.8(0.1)^{d}$ \\
\hline Rumex crispus & 1 & $89(2)^{a}$ & $4.9(0.1)^{\mathrm{a}}$ & $95(2)^{b}$ & $4.8(0.1)^{\mathrm{a}}$ & $91(2)^{a b}$ & $5.5(0.1)^{b}$ & $78(4)^{c}$ & $8.5(0.3)^{c}$ \\
\hline Rumex crispus & 2 & $71(3)^{a}$ & $6.7(0.1)^{\mathrm{a}}$ & $81(3)^{b}$ & $6.5(0.1)^{\mathrm{a}}$ & $83(3)^{b}$ & $6.9(0.1)^{b}$ & $46(4)^{c}$ & $9.2(0.3)^{c}$ \\
\hline Spergula arvensis & 1 & $90(2)^{a}$ & $1.4(0.1)^{\mathrm{a}}$ & $91(2)^{a}$ & $1.4(0.0)^{\mathrm{a}}$ & $94(2)^{a b}$ & $1.5(0.1)^{\mathrm{a}}$ & $70(3)^{c}$ & $4.2(0.2)^{b}$ \\
\hline Spergula arvensis & 2 & $87(0)^{a}$ & $2.9(0.1)^{a}$ & $92(2)^{a}$ & $2.9(0.1)^{\mathrm{a}}$ & $66(3)^{b}$ & $5.8(0.2)^{b}$ & $52(2) b c$ & $14.4(3.3)^{\mathrm{c}}$ \\
\hline
\end{tabular}


Table 4. Results of heat treatments at an exhaust gas temperature of $110{ }^{\circ} \mathrm{C}$ for durations of 2,4 , and $6 \mathrm{~s}$ with standard errors ( ). $d \times 100 \mathrm{denotes}$ the percentage of seeds that germinated during the experiment (\%). $t_{50}$ denotes the time (days) when $50 \%$ of the seeds (that germinated during the 16 days) had germinated. A dash (-) means no germination. All species parameters, which were significantly different, are marked with different letters.

\begin{tabular}{|c|c|c|c|c|c|c|c|c|c|}
\hline \multicolumn{10}{|c|}{ Treatment at $110^{\circ} \mathrm{C}$} \\
\hline \multirow[b]{2}{*}{ Species } & \multirow[b]{2}{*}{ Series } & \multicolumn{2}{|c|}{ Control } & \multicolumn{2}{|r|}{$2 \mathrm{~s}$} & \multicolumn{2}{|c|}{$4 \mathrm{~s}$} & \multicolumn{2}{|c|}{$6 s$} \\
\hline & & $d$ & $t_{50}$ & $d$ & $t_{50}$ & $d$ & $t_{50}$ & $d$ & $t_{50}$ \\
\hline Alopecurus myosuroides & 1 & $66(3)^{a}$ & $4.2(0.1)^{\mathrm{a}}$ & $72(3)^{a}$ & $5.6(0.2)^{b}$ & $15(120)^{a}$ & $19(18.0)^{a b}$ & - & - \\
\hline Alopecurus myosuroides & 2 & $77(3)^{a}$ & $5.3(0.1)^{\mathrm{a}}$ & $67(5)^{b}$ & $6.9(0.2)^{b}$ & - & - & - & - \\
\hline Centaurea cyanus & 1 & $93(2)^{a}$ & $1.3(0.1)^{\mathrm{a}}$ & $98(1)^{b}$ & $1.9(0.0)^{b}$ & $50(161)^{a b}$ & $24(31.4)^{a b}$ & - & - \\
\hline Centaurea cyanus & 2 & $96(1)^{a}$ & $2.8(0.0)^{\mathrm{a}}$ & $93(2)^{a}$ & $2.7(0.0)^{a}$ & $18(33)^{b}$ & $19(19.7)^{a}$ & - & - \\
\hline Geranium pusillum & 1 & $92(2)^{a}$ & $1.5(0.1)^{\mathrm{a}}$ & $89(2)^{a}$ & $1.6(0.1)^{b}$ & - & - & - & - \\
\hline Geranium pusillum & 2 & $90(2)^{a}$ & $1.8(0.1)^{\mathrm{a}}$ & $70(3)^{b}$ & $2.8(0.1)^{b}$ & - & - & - & - \\
\hline Lapsana communis & 1 & $95(2)^{a}$ & $4.1(0.1)^{\mathrm{a}}$ & $15(5)^{b}$ & $13.7(1.7)^{b}$ & $13(30)^{b}$ & $25(12.2)^{a b}$ & - & - \\
\hline Lapsana communis & 2 & $90(2)^{a}$ & $4.5(0.1)^{\mathrm{a}}$ & $9(2)^{b}$ & $11.5(0.9)^{b}$ & - & - & - & - \\
\hline Lolium perenne & 1 & $89(2)^{a}$ & $6.7(0.1)^{\mathrm{a}}$ & $67(4)^{b}$ & $9.6(0.3)^{b}$ & - & - & - & - \\
\hline Lolium perenne & 2 & $85(3)^{a}$ & $6.8(0.1)^{\mathrm{a}}$ & $62(4)^{b}$ & $9.8(0.3)^{b}$ & - & - & - & - \\
\hline Tripleurospermum inodorum & 1 & $94(2)^{a}$ & $2.5(0.1)^{\mathrm{a}}$ & $42(4)^{b}$ & $8.4(0.2)^{b}$ & - & - & - & - \\
\hline Tripleurospermum inodorum & 2 & $92(2)^{a}$ & $3.9(0.1)^{\mathrm{a}}$ & $5(1)^{b}$ & $12.3(0.3)^{b}$ & - & - & - & - \\
\hline Rumex crispus & 1 & $89(2)^{a}$ & $4.9(0.1)^{\mathrm{a}}$ & $75(3)^{b}$ & $7.2(0.3)^{b}$ & - & - & - & - \\
\hline Rumex crispus & 2 & $71(3)^{a}$ & $6.7(0.1)^{\mathrm{a}}$ & $50(4)^{b}$ & $6.7(0.2)^{\mathrm{a}}$ & - & - & - & - \\
\hline Spergula arvensis & 1 & $90(2)^{a}$ & $1.4(0.1)^{\mathrm{a}}$ & $13(5)^{b}$ & $12.8(2.6)^{b}$ & - & - & $15(351)^{\mathrm{a}}$ & $17(7.5)^{b}$ \\
\hline Spergula arvensis & 2 & $87(0)^{a}$ & $2.9(0.1)^{\mathrm{a}}$ & $12(2)^{b}$ & $19(18.5)^{\mathrm{a}}$ & - & - & - & - \\
\hline
\end{tabular}


A large fraction of the seed samples of C. cyanus (63\% and $47 \%$ ) and a minor fraction of the seed samples of $L$. perenne $\left(29 \%\right.$ and $1 \%$ ) were able to germinate when they were exposed to $140{ }^{\circ} \mathrm{C}$ for $2 \mathrm{~s}$, while only a small fraction of G. pussilum and S. arvensis were able to germinate in series $2(13 \%$ and $4 \%$, respectively). When seed samples were exposed to $140{ }^{\circ} \mathrm{C}$ for $6 \mathrm{~s}$, they lost their germination ability (Table 5).
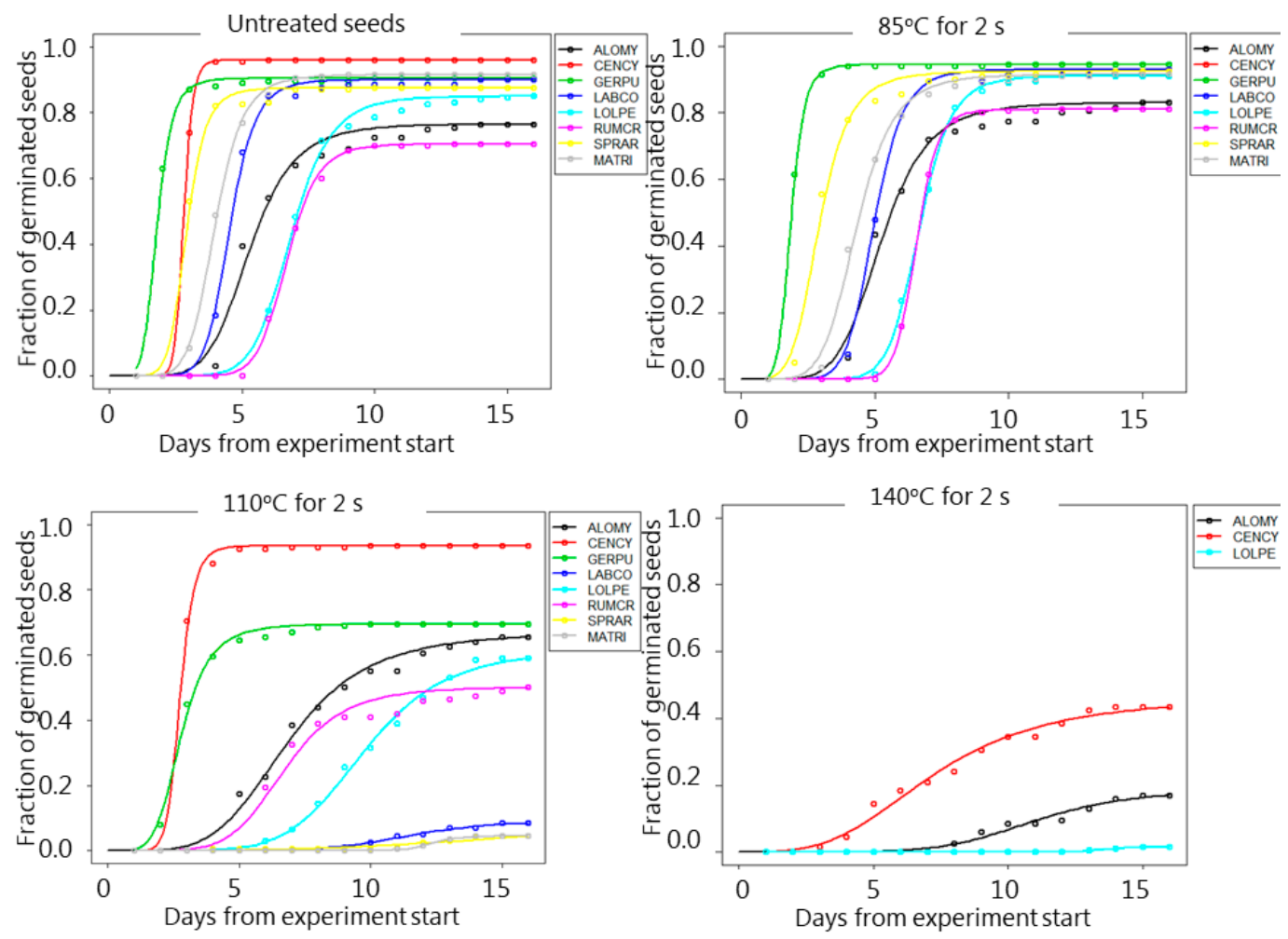

Figure 3. Series 2. Germination curves of weed seeds after they were exposed to exhaust gas for $2 \mathrm{~s}$ at temperatures of $75^{\circ} \mathrm{C}, 110^{\circ} \mathrm{C}$, and $140{ }^{\circ} \mathrm{C}$, respectively. A. myosuroides = ALOMY; C. cyanus = CENCY; G. pusillum $=$ GERPU; L. communis $=$ LAPCO; L. perenne $=$ LOLPE; R. crispus = RUMCR; S. arvensis $=$ SPRAR; T. inodorum $=$ MATIN. Species not shown at $140{ }^{\circ} \mathrm{C}$ did not germinate. Points are means of exact counts. Lines are estimated germination curves base on counts [see Equation (1)].

Table 5. Results of heat treatments at an exhaust gas temperature of $140{ }^{\circ} \mathrm{C}$ for durations of 2,4 , and $6 \mathrm{~s}$ with standard errors ( ). $d \times 100$ denotes the percentage of seeds that germinated during the experiment (\%). $t_{50}$ denotes the time (days) when $50 \%$ of the seeds (that germinated during the 16 days) had germinated. A dash (-) means no germination. All species parameters, which were significantly different, are marked with different letters. Numbers marked with different letters are significantly different.

\begin{tabular}{|c|c|c|c|c|c|c|c|c|c|}
\hline \multicolumn{10}{|c|}{ Treatment at $140^{\circ} \mathrm{C}$} \\
\hline \multirow[b]{2}{*}{ Species } & \multirow[b]{2}{*}{ Series } & \multicolumn{2}{|c|}{ Control } & \multicolumn{2}{|c|}{$2 \mathrm{~s}$} & \multicolumn{2}{|c|}{$4 \mathrm{~s}$} & \multicolumn{2}{|c|}{$6 s$} \\
\hline & & $d$ & $t_{50}$ & $d$ & $t_{50}$ & $d$ & $t_{50}$ & $d$ & $t_{50}$ \\
\hline Alopecurus myosuroides & 1 & $66(3)^{a}$ & $4.2(0.1)^{\mathrm{a}}$ & $15(10)^{b}$ & $15.0(3.7)^{\mathrm{b}}$ & - & - & - & - \\
\hline Alopecurus myosuroides & 2 & $77(3)^{a}$ & $5.3(0.1)^{\mathrm{a}}$ & $19(3)^{b}$ & $10.9(0.7)^{b}$ & - & - & - & - \\
\hline Centaurea cyanus & 1 & $93(3)^{a}$ & $1.3(0.1)^{\mathrm{a}}$ & $63(7)^{b}$ & $9.5(1.1)^{b}$ & $2.5^{c}$ & $12.5^{c}$ & - & - \\
\hline Centaurea cyanus & 2 & $96(1)^{a}$ & $2.8(0.0)^{\mathrm{a}}$ & $47(4)^{b}$ & $7.3(0.5)^{b}$ & - & - & - & - \\
\hline Geranium pusillum & 1 & $92(2)^{a}$ & $1.5(4.8)^{\mathrm{a}}$ & $13(3)^{b}$ & $16.0(16.0)^{\mathrm{a}}$ & - & - & - & - \\
\hline Lolium perenne & 1 & $89(2)^{a}$ & $6.7(8.0)^{\mathrm{a}}$ & $29(108)^{a}$ & $31.1(31.1)^{\mathrm{a}}$ & - & - & - & - \\
\hline Lolium perenne & 2 & $85(3)^{a}$ & $6.8(10.0)^{a}$ & $1(1)^{b}$ & $13.5(0.5)^{b}$ & - & - & - & - \\
\hline Spergula arvensis & 1 & $90(2)^{a}$ & $1.4(4.6)^{\mathrm{a}}$ & $41.2(3.8)^{b}$ & $6.8(0.5)^{b}$ & - & - & - & - \\
\hline
\end{tabular}




\section{Discussion}

Increasing temperatures and time of exposure to exhaust gases resulted in decreasing germination ability for all species tested. This general trend was the same in both trial series, but the germination response varied slightly for all species between the two-trial series (Table 3 ).

The germination percentage of $A$. myosuroides and $R$. crispus increased significantly according to the Tukey range test $(p$-value $=0.05)$ when the seeds were exposed to $75^{\circ} \mathrm{C}$ or $85^{\circ} \mathrm{C}$ (Tables 3 and 4 ). The glumes of some of the seeds of $A$. myosuroides may have been released by the heating, and the heat may have broken the seed coat of $R$. crispus, resulting in a faster water uptake and germination. It is well known that heat from fires can release seed dormancy in seeds with impermeable seed coats $[27,28]$. Heat shock influences germination by scarifying seeds that have hard and impermeable covers, thereby allowing water and oxygen exchange, as well as by removing inhibitory waxy substances on seeds [29-32]. The interval between optimal temperature and onset of denaturation is narrow and might be separated by only $10{ }^{\circ} \mathrm{C}$. Denaturation might occur at $40-50{ }^{\circ} \mathrm{C}$ in imbibed seeds [33]. Therefore, heat from exhaust gas may release dormancy of weed seeds and could allow farmers to control the weeds before the next crop has to be established.

The final germination percentage of R. crispus declined by $18 \%$ from the first to the second series, while $t_{50}$ increased by approximately one and a half days. Baskin and Baskin [34] found that the seed of R. crispus did not have any dormancy when stored under natural conditions. However, they found that seeds stored at constant low temperature sometimes induced seed dormancy. As the seeds were stored at ${ }^{\circ} \mathrm{C}$ between the two-trial series, this may have also contributed to the variation between the two series. As the first series was done on fresh seeds, that series has more real life relevance.

Seed samples exposed to $110^{\circ} \mathrm{C}$ and $140^{\circ} \mathrm{C}$ germinated considerably slower than seeds exposed to lower temperatures (higher $t_{50}$ values, which in some cases were estimated to happen outside of the experiment period of 16 days). In some cases, this resulted in larger standard errors of the model parameters because the $t_{50}$ and the upper limits ( $d$ parameters) were more uncertainly estimated, which probably could have been avoided if the durations of the germination tests were extended considerably (Tables 4 and 5).

An important outcome of the experiments was to determine the germination rate after 16 days. The experiments were finished after 16 days for all species, although the International Seed Testing Association (ISTA) [35] recommends a duration of 10-14 days for germination tests for most species. However, for some species, it can be appropriate to increase the duration. Furthermore, the germination of some species can be stimulated by pre-chilling and the addition of chemicals (e.g., $0.2 \% \mathrm{KNO}_{3}$ ) to release dormancy [36,37]. Thus, the germination abilities for some of the species and the treatments might have been larger if we had increased duration of the germination tests and used methods to improve the germination.

Exposing seeds to $110{ }^{\circ} \mathrm{C}$ for $2 \mathrm{~s}$ affected the germination ability of all species negatively except $\mathrm{C}$. cyanus, which has the largest seeds of all the species (Table 1). This might indicate that weed plants with large seeds are less sensitive to short heat treatments than species with small seeds. Spergula arvensis, which is one of the species with the smallest seeds and seed weight, was the only species where a certain fraction of the seed sample $(15 \%)$ was able to germinate even after $6 \mathrm{~s}$ of exposure to $110^{\circ} \mathrm{C}$ (Table 4).

We would expect that more energy was spent to heat up a large seed than a small seed to break cell walls and damage other cell structures. The sensitivity of the seed to heat probably also depends on the thickness of the seed coat, the structure, the morphology of the seed (e.g., glumes, protecting hairs and waxes), and the water content. Hanley et al. [32] found that, while seed size may be a useful general predictor of the sensitivity to heat shock, the interaction between seed size and the ability to withstand different thermal shock temperatures is complex. The effect of a short heating of wet or immature seeds with high water content might be less because the energy is being spent on water evaporation. A combine harvester may also harvest not fully matured weed seeds, which probably have higher water content than the dry seeds we chose. 
Germination rates of seeds treated in $2 \mathrm{~s}$ at $140{ }^{\circ} \mathrm{C}$ were all significantly reduced according to the Tukey range test (Table 5). However, seeds of A. myosuroides, C. cyanus, G. pusillum, L. perenne, and $S$. arvensis were still able to germinate at rates between $1 \%$ and $63 \%$. No seeds treated for $6 \mathrm{~s}$ at $140{ }^{\circ} \mathrm{C}$ were able to germinate (Table 5).

There were approximately three months between the two trial series, and as seeds are living organisms responding individually to environmental changes, some degree of variation was expected after three months of storage. Furthermore, as the germination was only recorded once a day and the time of the day varied somewhat, this variation could also have affected the precision of the estimated germination curves. It is noteworthy that the germination percentages of C. cyanus, G. pussillum, L. perenne, L. communis, S. arvensis, and T. inodorum were at the same level between replicates and series (low standard error) in the untreated germination tests (Table 3).

We conclude that exhaust gas can kill or reduce germination ability of weed seeds if the temperature is high enough and the exposure time is long enough (approximately $140{ }^{\circ} \mathrm{C}$ in 4 to $6 \mathrm{~s}$ ). Different weed species may vary in their response, however, as seen in our results. We encourage companies producing combine harvesters to consider how they can develop the concept to use the exhaust gas constructively to kill the weed seeds before the weed seeds normally are returned to the field. Developing a combine harvester using the waste energy from the exhaust gas to kill weed seeds or reduce seed germination may be a way to avoid vigorous weed seeds being returned to the field. Thereby, the seeds are not incorporated into the soil seed bank, creating new weed problems in the coming season. However, many weed species shatter a smaller or larger proportion of their seeds before harvest [38,39]; therefore, the effect strongly depends on the weed composition in the field. Walsh and Powels [40] found that some of the most important weed species in Australia-L. rigidum, Raphanus raphanistrum L., Bromus spp., and Avena fatua L.-retained 85\%, 99\%, 77\%, and $84 \%$ of their seeds above a $15 \mathrm{~cm}$ harvest cutting height at wheat (Triticum aestivum L.) maturity. Westerman and Gerowitt [41] studied seed production above and below cutting height of maize fields close to the anticipated harvest date. Weed density varied from 56 to 568 weeds $\mathrm{m}^{-2}$ and weed seed production from 886 to 229,256 seeds $\mathrm{m}^{-2}$. The main weeds were Chenopodium album $\mathrm{L}$. and Echinochloa crus-galli (L.) P. Beauv. In general, either weed plants were small and produced few seeds that were largely found below the cutting height of maize, or they were tall and produced numerous seeds that were largely found well above the cutting height. Therefore, cutting height and the composition of the weed flora are crucial factors determining the effects of destroying harvested weed seeds on the soil seed bank.

We used a small combine harvester with a relatively small engine for harvesting small research trials. Conventional combine harvesters have a much larger engine, generating higher temperatures and speed/pressure of the exhaust gas, which we expect would be even more damaging to weed seeds. Depending of the size of the engine of a combine harvester, the temperature of the exhaust gas measured directly behind the turbocharger of the engine can reach between $400{ }^{\circ} \mathrm{C}$ and $480{ }^{\circ} \mathrm{C}$ during harvesting. At the outlet, the exhaust gas is usually kept at a temperature of approximately $200^{\circ} \mathrm{C}$ to avoid fire hazards [19]. The weed seeds are transported through the combine harvester together with the chaff. The chaff may have an insulating effect protecting weed seeds from the heat from the exhaust gas. In that case, the temperature needs to be higher to damage the seeds. However, if the weed seeds are separated from the chaff, for example, by sieves, a higher temperature is not needed. A combine harvester works under dry conditions, and there is a risk that overheated material may accidentally catch fire. We conducted a small experiment (not shown) in which wheat chaff was placed directly over the exhaust pipe in the filter for $2 \mathrm{~min}$. The exhaust gas had an output temperature of $200{ }^{\circ} \mathrm{C}$, and the chaff did not show any sign of ignition. If we reduce the temperature $\left(<140{ }^{\circ} \mathrm{C}\right)$, we may eliminate the risk of fire and still kill a large proportion of the weed seeds and reduce seed germination of the rest (increasing $t_{50}$ and decreasing $d$ ). Glasner et al. [39] exploited how heat could be used to kill weed seeds of nine common weed species treated with temperatures of $50{ }^{\circ} \mathrm{C}, 100^{\circ} \mathrm{C}$, $150{ }^{\circ} \mathrm{C}, 200{ }^{\circ} \mathrm{C}$, and $250^{\circ} \mathrm{C}$ for $0,2,5,10$, and $20 \mathrm{~s}$, respectively. They found that $50^{\circ} \mathrm{C}$ and $100{ }^{\circ} \mathrm{C}$ did not damage the seeds of any of the species significantly at any of the durations. Depending on the 
duration, $150{ }^{\circ} \mathrm{C}$ gave varying results. However, when seeds of $A$. myosuroides were exposed to $250{ }^{\circ} \mathrm{C}$ for $5 \mathrm{~s}$, the germination was significantly repressed. When seeds were exposed to $250^{\circ} \mathrm{C}$ for more than $10 \mathrm{~s}$, most of the species were killed. Our results with exhaust gas were more promising because we did not need durations as long or temperatures as high as Glasner et al. [39].

The great volume and the velocity of the exhaust gas are main factors driving the heat distribution in the seeds and thus the effect on the weed seeds. To ensure a significant difference between the velocity of the exhaust gas and the seeds, the seeds have to be kept in place during the treatment, which is another challenge for developing the system.

Several common weed species in Northern Europe may remain small in the crop [e.g., Poa annua L., Stellaria media (L.) Vill., Viola arvensis Murray, and Veronica sp.], and their seeds may be placed below the header and escape the combine harvester. However, in a dense, well-fertilized crop, light competition results in longer internodes and higher plants improving the condition for weed seed harvesting [42].

\section{Conclusions}

The experiments showed that the germination of weed seeds was affected severely by the exhaust gas even at short durations. All weed seeds died when they were exposed to $140^{\circ} \mathrm{C}$ for $6 \mathrm{~s}$. The implementation of the method would be predicted to reduce the amount of viable and vigorous seeds in the soil seed bank over time. However, the germination ability of seeds exposed to $75^{\circ} \mathrm{C}$ and $85^{\circ} \mathrm{C}$ did not considerably decline at any of the durations. Two seconds of exposure indicated an increased germination compared to the controls, although this was not statistically significant $(p>0.05)$. When seeds were exposed to exhaust gas with a temperature of $110^{\circ} \mathrm{C}$, most species were affected even at $2 \mathrm{~s}$ duration, but the effect varied between the species. We conclude that exploiting exhaust gas from combine harvesters has the potential to kill or reduce the germination of weed seeds and should be investigated further. Key issues that need to be addressed when constructing the harvester include how the seed can be trapped and exposed to high temperature exhaust gas under high pressure (gas velocity) while avoiding fire hazard.

Author Contributions: K.J. and J.A.J. conducted the experimental work and the statistical analyses supervised by Z.B. and C.A. and wrote a draft of the manuscript. C.A. wrote the final manuscript. All authors reviewed and accepted the manuscript.

Funding: This work was done as a part of the project: 105 SWEEDHART-Separation of weeds during harvesting and hygienisation to enhance biomass production in the long term. The activity was conducted under the "Joint European research projects in the field of Sustainable and Resilient Agriculture." under ERA-NET Cofund FACCE SURPLUS 2015. We thank Innovation Fund Denmark for the financial support.

Acknowledgments: We thank our partners in the project Christoph Glasner and Robert Josef, Fraunhofer-Institut für Umwelt-, Sicherheits- und Energietechnik UMSICHT, Oberhausen, Germany, and Christopher Vieregge and Ralf Boelling CLAAS Selbstfahrende Erntemaschinen $\mathrm{GmbH}$, Harsewinkel, Germany, for inspiration and valuable discussions.

Conflicts of Interest: The authors declare no conflict of interest. The funders had no role in the design of the study, in the collection, analyses, or interpretation of data, in the writing of the manuscript, or in the decision to publish the results.

\section{References}

1. FAO. AGP_Weeds. 2017. Available online: http://www.fao.org/agriculture/crops/thematic-sitemap/theme/ biodiversity/weeds/en/ (accessed on 12 September 2019).

2. Heap, I. Herbicide resistant weeds. In Integrated Weed Management; Pimental, D., Peshin, E., Eds.; Springer: Dordrecht, The Netherlands, 2014; pp. 281-301.

3. Duke, S. Why have no new herbicide modes of action appeared in recent years? Pest Manag. Sci. 2011, 68, 505-512. [CrossRef]

4. Andreasen, C.; Streibig, J.C. Evaluation of changes in weed flora in arable fields of Nordic countries-Based on Danish long-term surveys. Weed Res. 2011, 51, 214-226. [CrossRef] 
5. Chauvel, B.; Guillemin, J.-P.; Gasquez, J.; Gauvrit, C. History of chemical weeding from 1944 to 2011 in France: Changes and evolution of herbicide molecules. Crop Prot. 2012, 42, 320-326. [CrossRef]

6. Funk, C.; Kennedy, B. The New Food Fights: U.S. Public Divides over Food Science, Differing Views on Benefits and Risks of Organic Foods, GMOs as Americans Report Higher Priority for Healthy Eating; Pew Research Center: Washington, DC, USA, 2016.

7. Liebmann, M.; Dyck, E. Crop rotation and intercropping strategies for weed management. Ecol. Appl. 1993, 3, 92-122. [CrossRef]

8. Melander, B.; Liebman, M.; Davis, A.S.; Gallandt, E.R.; Bàrberi, P.; Moon, A.; Rasmussen, J.; van der Weide, R.; Vidotto, F. Non-chemical weed management. In Weed Research: Expanding Horizons; Hatcher, P.E., Froud-Williams, R.J., Eds.; John Wiley \&Sons Ltd.: West Sussex, UK, 2017; pp. 245-270.

9. Robinson, R.A.; Sutherland, W.J. Post-war changes in arable farming and biodiversity in Great Britain. J. Appl. Ecol. 2002, 39, 157-176. [CrossRef]

10. Andreasen, C.; Jensen, H.A.; Jensen, S.M. Decreasing diversity in the soil seed bank after 50 years in Danish arable fields. Agric. Ecosyst. Environ. 2017, 259, 61-71. [CrossRef]

11. Osteen, C.D.; Fernandez-Cornejo, J. Herbicide use trends: A backgrounder. Choices 2016, 31, 31-37.

12. Roberts, H.A.; Feast, P.M. Fate of seeds of some annual weeds in different depths of cultivated and undisturbed soil. Weed Res. 1972, 12, 316-324. [CrossRef]

13. Roberts, H.A.; Feast, P.M. Emergence and longevity of seeds of annual weeds in cultivated and undisturbed soil. J. Appl. Ecol. 1973, 10, 133-143. [CrossRef]

14. Walsh, M.; Newman, P.; Powles, S. Targeting weed seeds in-crop: A new weed control paradigm for global agriculture. Weed Technol. 2013, 27, 431-436. [CrossRef]

15. Lewis, J. Longevity of crop and weed seeds: Survival after 20 years in the soil. Weed Res. 1973, 13, $179-191$. [CrossRef]

16. Jensen, H.A. Seed Burial Experiment at the Danish State Seed Testing Station, 1934-1983. Seed Test. Int. 2016, 151. Available online: https://www.seedtest.org/upload/cms/user/Danish-Seed-Burial-Experiment.pdf (accessed on 12 September 2019).

17. Walsh, M.J.; Harrington, R.B.; Powles, S.B. Harrington seed destructor: A new nonchemical weed control tool for global grain crops. Crop Sci. 2012, 52, 1343-1347. [CrossRef]

18. StedmanTM. Stedman Cage Mill Primer. Available online: https://www.stedman-machine.com/ (accessed on 12 September 2019).

19. Vieregge, C. Personal Information. CLAAS Selbstfahrende Erntemaschinen GmbH; Vorentwicklung-Funktionstechnik: Harsewinkel, Germany, 2018.

20. Korsmo, E.; Vidme, T.; Fykse, H. Kosmos Ugras Pjansjer; Norsk Landbruk/Landbruksforlaget: Olso Norge, Norway, 1981.

21. Holm-Nielsen, C. Frø Fra de Dyrkede Land; Forskningscenter Flakkebjerg, Frederiksberg Bogtrykkeri: Copenhagen, Denmark, 1989.

22. Mossberg, B.; Stenberg, L. Den Nye Nordiske Flora; Gyldendal: Copenhagen, Denmark, 2003.

23. Andreasen, C.; Bitarafan, Z.; Fenselau, J.; Glasner, C. Exploiting waste heat from combine harvesters to damage harvested weed seeds and reduce weed infestation. Agriculture 2018, 8, 42. [CrossRef]

24. Ritz, C.; Streibig, J.C. Bioassay analysis using R. J. Stat. Softw. 2005, 12, 1-22. [CrossRef]

25. Ritz, C.; Pipper, C.B.; Streibig, J.C. Analysis of germination data from agricultural experiments. Eur. J. Agron. 2013, 45, 1-6. [CrossRef]

26. Hothorn, T.; Bretz, B.; Westfall, P. Simultaneous inference in general parametric models. Biom. J. 2008, 50, 346-363. [CrossRef]

27. Fidelis, A.; Daibes, L.F.; Martins, A.R. To resist or to germinate? The effect of fire on legume seeds in Brazilian subtropical grasslands. Acta Bot. Bras. 2016, 30, 1. [CrossRef]

28. Moreira, B.; Pausas, J.G. Tanned or Burned: The Role of Fire in Shaping Physical Seed Dormancy. PLoS ONE 2012, 7, e51523. [CrossRef]

29. Arcamone, J.; Jaureguiberry, P. Germination response of common annual and perennial forbs to heat shock and smoke treatments in the Chaco Serrano, central Argentina. Austral Ecol. 2018, 43, 567-577. [CrossRef]

30. Keeley, J.E.; Bond, W.J. Convergent seed germination in South African fynbos and Californian chaparral. Plant Ecol. 1997, 133, 153. [CrossRef] 
31. Hanley, M.E.; Fenner, M.; Neuman, G. Pre-germination heat shock and seedling growth of fire following Fabaceae from four Mediterranean-climate regions. Acta Oecol. 2001, 22, 315-320. [CrossRef]

32. Hanley, M.E.; Unna, J.E.; Darvill, B. Seed size and germination response: A relationship for fire-following plan species exposed to thermal shock. Oecologia 2003, 134, 18-22. [CrossRef] [PubMed]

33. Bewley, J.D.; Black, M. Seeds. Physiology of Development and Germination, 2nd ed.; Plenum: New York, NY, USA; London, UK, 1994.

34. Baskin, J.M.; Baskin, C.C. Does seed dormancy play a role in germination? Ecology of Rumex crispus. Weed Res. 1985, 33, 340-343. [CrossRef]

35. ISTA. International rules for seed Testing; The International Seed Testing Association (ISTA): Bassersdorf, Switzerland, 2011.

36. Copeland, L.O.; McDonald, M.B. Principles of Seed Science and Technology, 4th ed.; Kluwer Academic Publishers: Norwell, MA, USA, 2001; p. 488.

37. Yasin, M.; Andreasen, C. Breaking seed dormancy of Alliaria petiolata with phytohormones. Plant Growth Reg. 2015, 77, 307-315. [CrossRef]

38. Bitarafan, Z.; Andreasen, C. Seed Production and Seed Shattering of Black Grass (Alopecurus mysuroides) in Winther Wheat. In Proceedings of the 18th European Weed Research Society Symposium (EWRS 2018), Ljubjana, Slovenien, 17-21 June 2018; p. 181.

39. Glasner, C.; Vieregge, C.; Robert, J.; Fenselau, J.; Bitarafan, Z.; Andreasen, C. Evaluation of new harvesting methods to reduce weeds on arable fields and collect a new feedstock. Energies 2019, 12, 1688. [CrossRef]

40. Walsh, M.J.; Powles, S.B. High seed retention at maturity of annual weeds infesting crop fields highlights the potential for harvest weed seed control. Weed Technol. 2014, 28, 486-493. [CrossRef]

41. Westerman, P.R.; Gerowitt, B. The probability of maize biomass contamination with weed seeds. J. Plant Dis. Prot. 2012, 119, 68. [CrossRef]

42. Yasin, M.; Rosenqvist, E.; Andreasen, C. The effect of reduced light intensities on grass weeds species. Weed Sci. 2017, 65, 603-613. [CrossRef]

(C) 2019 by the authors. Licensee MDPI, Basel, Switzerland. This article is an open access article distributed under the terms and conditions of the Creative Commons Attribution (CC BY) license (http://creativecommons.org/licenses/by/4.0/). 